\title{
A chronological proposal for the huerta of Elche
}

\author{
Dominique F. Aviñó McChesney \\ University of Murcia \\ dominique@w3ti.com
}

\begin{abstract}
In this paper we propose an Andalusian chronology for the irrigated region of Elche which includes not only the area declared World Heritage by the UNESCO (Martínez, 1999) but also the whole irrigated area of what is called Camp $d^{\prime} E l x$. We also propose a historical evolution of the different parts constituting this landscape. We base our proposal on what we consider to be its main element: its hydraulic infrastructures. We will analyse from two different but complementary perspectives - that of their names and that of their measurements - the constructions made for collecting water and distributing it throughout the plots. In addition, we take into account the use of the tabuilla as a surface unit - which is still used today in the Camp $d^{\prime} E l x$ - as its etymology is undoubtedly Arabic and its value is based on the Islamic cubit.
\end{abstract}

Keywords: Irrigation, Andalusian, cubit, landscape, toponymy

\section{Introduction}

Irrigation has been the object of research since the early works of Thomas F. Glick, Pierre Guichard, André Bazzana, Patrice Cressier (1989) or Miquel Barceló (1989). For the first time, the study of agricultural landscapes was associated with Andalusian society. Glick $(1988,1992)$ was the first to emphasize the relationship between irrigation and the political and social system of al-Andalus; P. Guichard (1985, 1994 and 1995) and André Bazzana (1980 and 1986), gave special attention to the settlements of tribal farmsteads and their adjacent irrigated lands, when talking of Sharq al-Andalus. They all began an analysis of agrarian techniques and methods, including those related to the design of irrigated lands within their social, economical and political context. This great interest in research came hand in hand with progress in the field of medieval archaeology.

On the other hand, historic Valencian huertas have been studied recently because of their heritage value, as the works carried out by the Department of Geography of the University of Valencia ${ }^{1}$ within the Confederación Hidrográfica del Júcar show. These works cover almost every historic irrigation in the basin of the river Jucar, including those in the upper and mid basin of the Vinalopó. Although a complete study of the low Vinalopó is still to be made. Number 4 of the series Camins d'Aigua, dedicated to the canals of Elche and Crevillente tells us when dealing with historic buertas of the low Vinalopó that "we can see, again, one of those water landscapes (...) that contains a set of characteristics, elements, structures, overall design and social tradition that constitute a fundamental and remarkable part of the cultural heritage of our society" (Guinot and Selma, 2003). Our study of the buerta of Elche is based on the main physical evidence of its existence: water intake and water distribution systems, including open canals, ditches, checks and division boxes or dividers. We have studied the measures of this structures, more specifically, those of the Séquia Major (Major Canal) dividers, together with their names and some significant toponyms throughout the Camp d'Elx.

1 http://www.chj.es/es-es/ciudadano/libros/ On this website you can access cartographic resources of historic irrigation, inventories of hydraulic structures and studies about their origins and operation. 
Regarding measures and measurements, we have used the measures of the dividers of the Séquia Major described by Francisco Verde in 1666, completed later on by Roca de Togores in 1850 (De Hidalgo, 1851). We are aware of the difficulty involved in establishing an exact equivalence of the Islamic cubit, as it is not very accurate. The Islamic cubit ranges from over $50 \mathrm{~cm}$ to $70 \mathrm{~cm}$ for the Egyptian or rassasi cubit, and has values of over $40 \mathrm{~cm}$ and under $47 \mathrm{~cm}$ for mamuni cubit (Vallvé, 1976). However, we must say that the equivalences have been quite accurate in many of the cases analysed, with a clear predominance of multiples of the rassasi cubit of around $52 \mathrm{~cm}$ and $55 \mathrm{~cm}$ (and the so-called minor cubit of $41.79 \mathrm{~cm}$, equivalent of three quarters of this), and the mamuni cubit of $47 \mathrm{~cm}$.

On the other hand, the names of dividers and ditches suggest from the start their Andalusian origin, and after more exhaustive analysis, we can confirm that the vast majority of those names are purely Arabic, that is, they have not been translated into Castilian or Valencian terms but they have kept their Arabic form and have been adapted to the phonetic characteristics of Castilian or Valencian.

\section{General principles of hydraulic technology and their application to the irrigation system of Elche}

The layout of the irrigation canals and ditches in the buertas constitutes, as we have said before, the main evidence of the huertas' existence and features. Their trajectory fulfils the need to demarcate a territory and distribute the water throughout it: "Its design (...) is not a result of chance but of a thoughtful analysis of the territory, searching for solutions (...)" (Guinot and Selma, 2003: 8).

Two basic principles guide the construction of hydraulic infrastructures -gravitational force and rigidity- where the height of the water intake defines the whole system (Barceló, 1989; Kirchner and Navarro, 1994). And both these principles, which are the same for every irrigation system regardless of the size of the resulting irrigated area, require a thoughtful pre-design. Canals and ditches should have adequate gradients, not too level as this would produce the stagnation of the water, not too marked as this would cause damage.

Similarly, the location of dividers and ditches that start from the main canal responds to a previous calculation to get the water needed or assigned to each place. In this sense, like streets are planned at present bearing in mind the possibility of future expansion, some places would have been marked for future possible extension of irrigation, at the time the system was designed. We must take into consideration that the fewer stops along the main canal, the smaller the risk of erosion and of loss of water volume. These considerations lead us to believe in the existence of surveyors and engineers at the moment of the design of the irrigation system, as well as the existence of a unified and organized society: "Valencian historic irrigated lands are an example of social agreement and the collective desire of peaceful coexistence (...)" (Guinot and Selma, 2003: 9). 


\subsection{A description of the huerta of Elche}

The irrigated region that nowadays surrounds the city of Elche, in Alicante, consists of several orchards, most of them delimited by fences or palisades. Some of them are properties of what local farmers call senyorets ${ }^{2}$ (Jaén, 2002). To our knowledge, and as we explain throughout this paper, in the space which forms the historical Palm groves, large and small properties would have coexisted. We know that after the Christian conquest, a process of concentration of ownership into a few hands, often dead hands, occurred. It was a process exemplified to perfection in the case of Doctor Caro i Martí who, coming from an aristocratic family, was at the time of his death the owner of "olivar junt al ort de Gascon. Tros de olivar junt a Candalix. Tafulles junt Candalix. Tafulles junt lo ort del Real. Ort del Real. Casa del ort del Real. Ort del Colomer. Casa dita del Colomer. Orts del costat del carreró de Grañana. Casa del dit ort que trau porta en front lo carrer del Facho..." ${ }^{\prime 3}$. We also know that he bequeathed all his properties to the statue of the Virgin of the Assumption ${ }^{4}$. Doctor Caro was a descendant of one of the families that accompanied Jaime $I$ in his conquest of Elche. He was married to a noble woman, and decided in his will that all his properties would form an indivisible link, and after passing on to his only granddaughter, whose only child became a nun in a convent, would become the property of that statue.

The ownership roots of these groves, whether they be stately properties or tenancies in the form that they are known today, go back only about three centuries, as most have their origin in the eighteenth century (López, 1987). However, we believe that the cultivation area itself - with its limits and the physiognomy of its plots - came into being in the Andalusian period. We also believe that this irrigated area would have been much smaller than it is today, and there would have also been dry farming areas in the space between the perimeters of the various irrigation ditches. This seems to be confirmed in other irrigated areas such as the Valencian buerta through the reconstruction of medieval plots (Esquilache, 2011; González, 1996 and 2002). As noted by Enric Guinot, "actually, the extension of the historical buerta of Valencia is much smaller and it is delimited by the maximum perimeters of the irrigation canals of medieval Islamic origin" (Guinot, 2007: 62)

\footnotetext{
Owners of large estates.

http://www.elche.me/biografia/caro-marti-nicolas-el-doctor-caro Source: ibidem.
} 


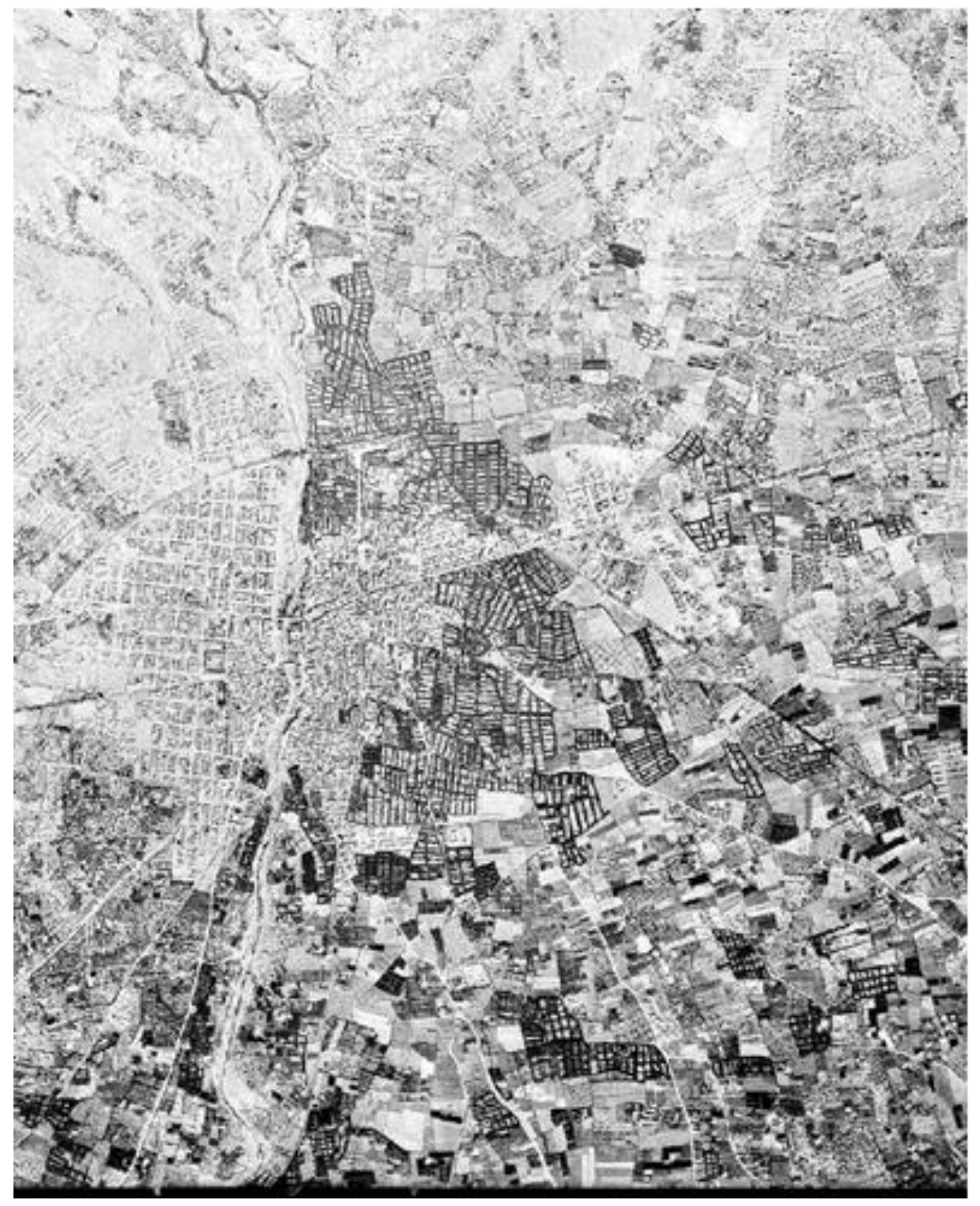

Fig.1. Aerial view of Elche and its irrigation area. Ruiz de Alda, military flight, 1929. Source: IGN (www.cnig.es).

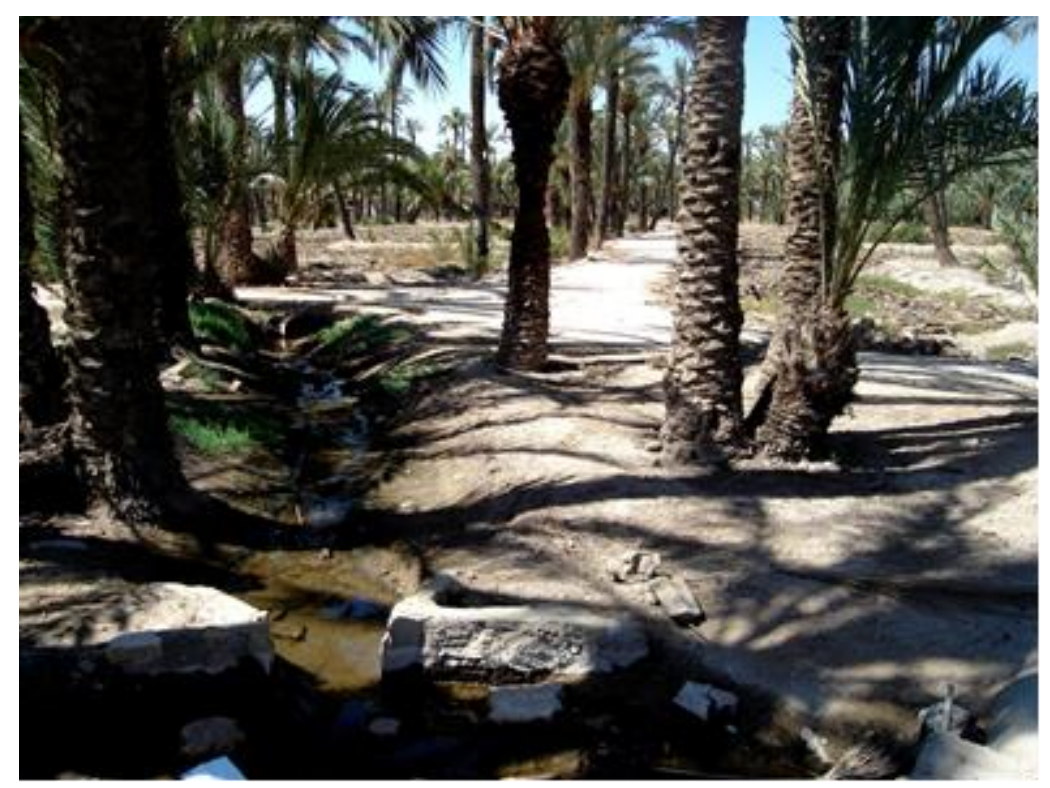

Fig.2. Orchard, Historical Palmeral, Elche. Photograph by D. Aviñó. 2007 


\subsection{Hydraulic infrastructures}

The specific irrigated area occupies the coastal plain, around the city and up to the reed beds and the albufera of Elche (Montesinos, 2004). This area starts where the dividers do and where the Marchena canal begins. The first and the only other fixed divider, together with that of Marchena, is Albinella. This divider separated the water for urban usage and, where it ends, the Séquia Major heads straight to the town centre. Before reaching the city, six ditches are derived to irrigate the northern area, all of them branching out of the left side of the main canal. Each one of these ditches originates from a divider with which it shares its name. All of these dividers are mobile, not fixed, which means that they can divert a specific quantity of water according to what is needed and available at each moment. They are called Carrell, Asnell, Anoi, Candalix and Real. (De Hidalgo, 1851; Guinot and Selma, 2003).

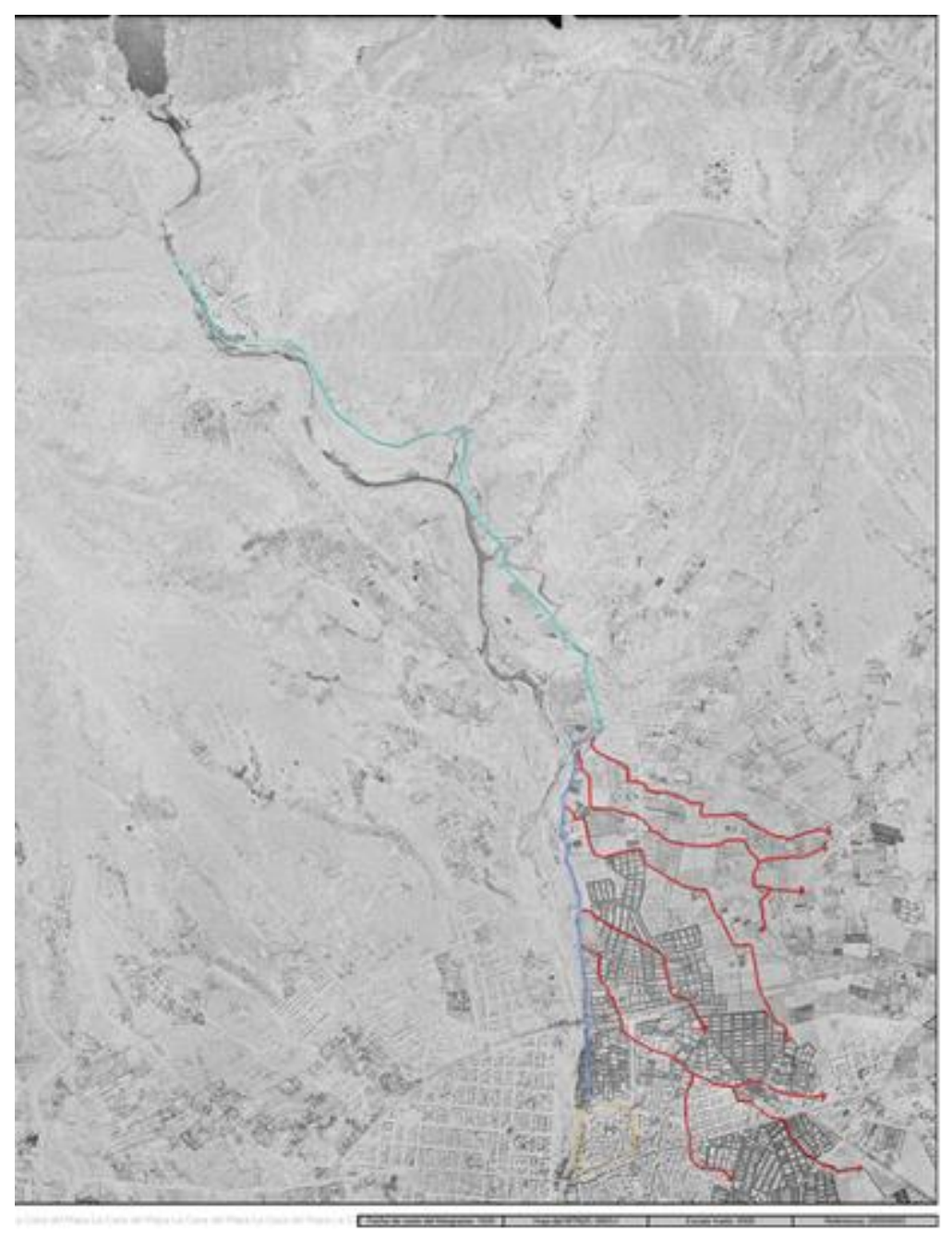

Fig.3: Aerial view of the Northern part of Elche, American military flight, 1956-57. First part of the Séquia Major (dark blue), the Séquia Major from where the irrigation begins (blue), the ditches of the northern part of the buerta (red), the perimeter of the medieval town (yellow). Source: IGN 
When it reached the town centre, the Séquia Major would have gone around the back of the Castle of Altamira, and after crossing its parade grounds, it would have crossed the city running next to the mosque-church of Santa María until leaving it through the East gate of the city - Gate of Alicante - (Borrego and Saranova, 1990). From there, heading southeast, the canal would have veered diagonally away from the river and the city. Along this stretch, several dividers follow one another: they are the Nijasa/Alignasa/Alinjassa, Abdet/Avet, Matrof, Alcanà, Nafís, Atufà, Cuñera and Saoni ditches. Next, at the divider called Aladia, the Séquia Major is divided in two and fans out from here together with the Aladia, el Franc, Alausa, Alborrocat, Anacla, Palombar and Carmadet/Avall/Sinoga ditches. (De Hidalgo, 1851; Guinot and Selma, 2003).

\section{The identification of the original design}

Elche's irrigation system is not free from the traditional controversy between those who attribute it to the Romans and those who claim an Andalusian origin for it. Moreover, this debate becomes even more passionate in this case due to the widespread predilection of local historians for "all things Roman". Thomas Glick considered this to be a sterile debate when its only aim is to attribute a specific achievement to a particular civilization, as it has been done so many times in the past. We completely agree with this. By addressing only isolated aspects of the issue, contradictory and allegedly valid conclusions can be reached. However, a more comprehensive analysis, based on actual physical evidence is more likely to lead to genuinely valid conclusions. As Miquel Barceló pointed out about when addressing this matter almost twenty years ago: "Proper identification and analysis of the fundamental structure of the original design allows us to identify the stages of development of a given system, and consequently evaluate their agricultural output and their population burden" (Barceló, 1989).

\subsection{Toponymy: the names of the orchards, the canals and the farmsteads}

3.1.1 Historic orchards. The names of the urban and peri-urban historic orchards are very recent, and we can hardly find any names that reveal an Andalusian origin. Besides, we have to face a significant handicap, because some orchards have more than one name, while we only know the name of others but not their location. In addition, there are some cases where there is a confusion between two different orchards ${ }^{5}$, or there have been constant changes to their boundaries throughout their history, which leads to the fragmentation of orchards that are known by different names.

Firstly, there are several orchards that take the name of their owner at a given time, whether their proper name (de Malena, de José, de Vicentet, de Don Caludio, de Felip, de Revenga, de Malla, de Avellán, de Quito Escorina, de Sempere, de Sansano, de Toni Escorina, de Diego Escorina,

5 For the identification of the historic orchards we have used the information provided by the Special Protection Plan of the Palmeral, draw up by the city council of Elche, also adding some complementary information from the work of Vicente Serrano (Serrano,1996). 
de Botella, de Montenegro, de Bernia ? ?, de Quiles, ¿de Trabalón?, de Manxón), or their profession (de la Molinera, del Colomer, del Xocolater, ¿del Monjo?, del Pastoret, del Cura); or their nickname (del Belet/dels Belets?, del Novet?, de Nal?, de Rastoll, dels Pollos, dels Bous, de Rastoll, del Gat?, del Pessetero, de la Rogeta, del Motxo, de la Coronela, de la Mareta, de la Tía Casimira, del de Bacora, del Cebo, del Tío Massot,, del Tomballops, del Torreret o de la Bolsa, del Cabolo). Other orchards are named after their location or some significant feature (els Molins, del Partidor del Real o del Real, de la Parteta, de la Torre de Vaillos, de Baix, de l'Estació, del Balconet, dels Ullets, de la Creu del Terme, de la Barrera, del Clero, del Palmerar, de la Rinconá, de Villa Carmen, del Partidor, que no té portes, del Sol, dels Banquets, del Clot de les Tres, dels Pontos, de les Almàsseres, de l'Arbre, de Dins, de les Portes Encarnades, de la Torreta, del Matadero, de la Torreta de Verdi, del Fossar, del Bosquet, del Túnel, de la Bolsa o del Torreret, del Moli del Cèntim, del Contador, de l'Hospital, de l'Ege, de Cantallops $^{\top}$ ). There are also hagiotoponyms, which sometimes indicate the existence of a church nearby (de Sant Antoni y de l'Ermita de Sant Antoni, de la Marededéu', del Rosari, del Carme, de San Plácido, de la Mareta?).

In spite of the lack of toponyms with an Arabic etymology for these orchards, we still believe that some observations about their names could be made. To begin with, what attracts our attention is that the recent origin of those names contrasts with the fact that many of those orchards already existed in the Andalusian period. Furthermore, a lot of orchards are named after some construction or some distinctive feature, which means that their name is independent from who owned them and when, and derives from the existence of said construction or feature. Furthermore, some of the orchards called after their owners' name, profession or nickname are also known by the name of some descriptive characteristic. An explanation for this would be that these modern orchards are an extension of the Andalusian urban buerta and of the buertas of the outlying farmsteads whose boundaries changed over time either gradually turning into large properties concentrated in the hands of a few people or divided into small orchards that became the property of their tenants through the lengthening of their long lease contracts. The latter would have affected specially in peri-urban and outlying orchards, while the concentration that resulted in aristocratic or bourgeois properties would have affected the most central orchards.

3.1.2 Canals and farmsteads. As shown on Table 1 -where the main toponyms are listed - the vast majority of dividers and ditches have purely Arabic names. Prominent among them are those that correspond to common names that could be describing some physical feature or pointing to the existence of a remarkable element, whether a natural one - a tree, an orographic milestone, for example - or an artificial one - a structural element. We are referring to the following: Abdet, Aladia, Alausa, Albelló, Albinella, Alcaná, Alinjasa, Almeida, Anacla, Atufá, Daimés, Real, Matrof, Marchena and Nafis. We think that the names Anoy, Asnell, Candalix, Carrell and Cuñera could belong to this type too although we have some doubts as to their interpretation. In our view, this particular kind of toponyms are very revealing, even more so if we take into account the huge number of them that there are in Elche's hydraulic system. These names were given by Arabic speakers at a time when

6 Even though it is a surname, it does not match with any of its known owners. We think that it could be a previous name; if we take into consideration that Bernia is considered to be an Arabic word, it is maybe referring to a Moorish owner. This is a peri-urban orchard watered by the canal of Carrell-Cantallops (ditch of Carrell) and surely constituting a bigger orchard already disappeared.

7 Name of a site in Elche and also of a secondary ditch. It is the place where this ditch crossed the ravine of San Antón.

8 Called so for being the property of the statue of the Virgin of the Assumption. 
the physical characteristics to which they referred were meaningful enough to serve as identifiers. The survival of the original Arabic word instead of a later translation shows that the defining element would have been relevant at the time the name was given in the Andalusian period but it would no longer have been useful in a Christian society where it would sometimes lose its meaning and only the formal aspect of the word would remain.

Other toponyms, although fewer in number, also illustrate the likely Andalusian origin of these words as they appear to come from Arabic anthroponyms. These anthroponyms can be proper names or clan names. An example of a proper name that may refer to descendants of a particular individual would be Carmadet/Carmbadet. Toponyms probably related to clan names include Beniay, Boniol, Sahoní, Sinoga and perhaps Rabahali. We should mention at this point that we think there could be a duplication of names, given that the origins of Beniay and Boniol, on the one hand, and of Saboni and Sinoga, on the other, could coincide. Initially, we thought that both names - Beniay and Boniol - could come from the family of the Yabya, newly arrived in Tudmir from Africa, from whom the name Beniel which corresponds to a Murcian present-day town and to one of the canals of the buerta of Murcia - originates (Hernández, 1976: 159). However, we now believe that they might be two different names, one corresponding to that African family and the other one coming from the Yemeni family of the Banu Hayyay, or they might both have the same origin, associated with the Yemeni family. ${ }^{9}$ The other two names mentioned - Saboni and Sinoga - might derive in our view from the family name of the Sinhaya, present in alAndalus since the early stages of the conquest, though its presence became particularly significant from the time of the Almoravid conquest, as the Almoravid belonged to this tribe.

It is also meaningful that the anthroponyms mentioned above gave their names to canals and dividers as well as to farmsteads throughout the Camp $d^{\prime} E l x$, while only Candalix, Daimés and Marchena amongst the descriptive names were farmsteads. In the first case, that is, where a ditch and the farmstead irrigated by that ditch had the same name which came from an anthroponym, it seems evident that we are dealing with a process of carrying water to a pre-existing habitat. It means that the habitat was prior to the ditch, and the ditch would have been built to take water to the farmstead. On the other hand, in those cases where both a farmstead and a ditch have the same name, and this name derives from a common name, the process seems to would have been the reverse.

9 These considerations imply an important element in favour of the Yemeni origin of the hydraulic system of Elche, an idea that Thomas Glick has advocated, on the basis of the way the water is distributed, from units of time and associated to the sale of water. (Glick, 1984: 333). 
Table 1. Names of ditches, dividers and farmsteads.

\begin{tabular}{|c|c|c|c|c|}
\hline NAME & INTERPRETATION ${ }^{10}$ & DITCH/DIVIDER & FARMSTEAD & OTHERS ${ }^{11}$ \\
\hline Abet/Avet/Abdet ${ }^{12}$ & $\begin{array}{l}\text { from the Arabic root abd (to adore) } / \text { Abet } \\
\text { (proper name) }\end{array}$ & $\mathrm{X}$ & & $\mathrm{X}(\mathrm{R})$ \\
\hline Aladia & from al-adia (common, flat) & $\mathrm{X}$ & & \\
\hline Alausa & from Al-lawz (of the almond tree) & $\mathrm{X}$ & & \\
\hline Albelló & from al-balló (drainage canal) & $\mathrm{X}$ & & \\
\hline Albinella & from Al-binyana (built place) & $\mathrm{X}$ & & \\
\hline Alborrocat/Borrocat & from al-bury (of the tower) & $\mathrm{X}$ & & $\mathrm{X}(\mathrm{R})$ \\
\hline Alcaná & from al-qanat (water conveyance) & $\mathrm{X}$ & & \\
\hline Algoda & $\begin{array}{l}\text { from al-gudayyuir (water tank)/ from algayda } \\
\text { o gaydah (sandy terrain by the sea) }\end{array}$ & & & $\mathrm{X}(\mathrm{S})$ \\
\hline Algorós $^{13}$ & $\begin{array}{l}\text { from gurus? (root, with the meaning of } \\
\text { place suitable for cultivation) }\end{array}$ & X & & $X(S)$ \\
\hline Altabix/ ¿Aliabib? & $\begin{array}{l}\text { from tabhig (beautify or decorate / from } \\
\text { tabis (silk) }\end{array}$ & & & $\mathrm{X}(\mathrm{S})$ \\
\hline Alinjasa & from Al-inyas (of the pear tree) & $\mathrm{X}$ & & \\
\hline Almeida & from al-media (slab)/from atmeidan (field) & $\mathrm{X}$ & & $\mathrm{X}$ \\
\hline Anacla & (low and boxed land) & $\mathrm{X}$ & & \\
\hline Anoy & from anauir (the waterwheels)? & $\mathrm{X}$ & & \\
\hline Asnell & from bisn (fortified site)? & $\mathrm{X}$ & & \\
\hline Atufá & from tuffah (apple tree) & $\mathrm{X}$ & & \\
\hline Beniabez & $\begin{array}{l}\text { from Beni Abet? (patronymic+proper } \\
\text { name) }\end{array}$ & & $\mathrm{X}$ & \\
\hline Beniandala $^{14}$ & & & $\mathrm{X}$ & \\
\hline Beniambrós ${ }^{15}$ & $\begin{array}{l}\text { Banu Ambros } \\
\text { (patronymic+ proper name)/ from Amrús } \\
\text { (red) }\end{array}$ & & $\mathrm{X}$ & \\
\hline Beniamor $^{16}$ & from banu Amir?(descendants of Amir?) & & $\mathrm{X}$ & \\
\hline Beniay & $\begin{array}{l}\text { from banu Hayyay (important Arabian } \\
\text { lineage) }\end{array}$ & $\mathrm{X}$ & $\mathrm{X}$ & \\
\hline Benibosch/Beniboc & & & $\mathrm{X}$ & \\
\hline Benicaixer & $\begin{array}{l}\text { from Banu (patronymic) + qasr (castle, } \\
\text { fortification)? }\end{array}$ & & $\mathrm{X}$ & \\
\hline Benichuchell & $\begin{array}{l}\text { from Banu Cherchel (demonym, the } \\
\text { population of Cherchel, city in Argelia ? }\end{array}$ & & $\mathrm{X}$ & \\
\hline Benieschicent & & & $\mathrm{X}$ & \\
\hline Benigomá17 & $\begin{array}{l}\text { from Banu Gumara (patronymic+ Berber } \\
\text { tribe) }\end{array}$ & & $\mathrm{X}$ & \\
\hline Benimonder & $\begin{array}{l}\text { from Banu al-Mundir (patronymic+proper } \\
\text { name) }\end{array}$ & & $\mathrm{X}$ & \\
\hline Benisarcó $^{18}$ & $\begin{array}{l}\text { from Banu Zarqun (patronymic+proper } \\
\text { name) / banu sharq (patronymic+"East") }\end{array}$ & & $\mathrm{X}$ & \\
\hline Benisser & from Banu Issa ${ }^{19}$ (patronymic+Arabian clan) & & $\mathrm{X}$ & \\
\hline Benisueili & & & $\mathrm{X}$ & \\
\hline Benixell & & & $\mathrm{X}$ & \\
\hline Boniel/Boniol ${ }^{20}$ & $\begin{array}{l}\text { from banu Hayyay (Yemeni family/from } \\
\text { banu Yabya (Berber demonyc name) }\end{array}$ & $\mathrm{X}$ & $\mathrm{X}$ & \\
\hline Candalix & $\begin{array}{l}\text { plant species (baobab)/ vernacular name of } \\
\text { Mauritania: qandalis? / from Arabic jandarús } \\
\text { (cereal, millet) }\end{array}$ & $\mathrm{X}$ & $\mathrm{X}$ & \\
\hline
\end{tabular}

10 Asín, 1944; Barceló, 1982a and 1982b; Caridad, 2004; De Epalza and Rubiera, 1986; Faure, 1977; Guichard, 1991; Hernández, 1976; Ivars, 2003; Jacinto, 2006; Manzano, 1995; Oliver, 2001; Pockington, 2010; Ranz and López, 1997; Roselló, 2007; Rubiera, 1985; Serrano, 1992.

11 Road (R), site (S), orchard (O), lands (L)

12 Place name present at inland Alicante.

13 In the Valencian huerta there is a canal of Algirós.

14 Place name present at the de Filabres Mountains, in Almería.

15 Place name present at Murcia.

16 Place name present at Mallorca.

17 A place name Benigotmar is present at Mallorca.

18 Place name present at Murcia.

19 Clan present at Murcia and Valencia.

20 Place name present at Murcia. 


\begin{tabular}{|c|c|c|c|c|}
\hline NAME & INTERPRETATION ${ }^{10}$ & DITCH/DIVIDER & FARMSTEAD & OTHERS 11 \\
\hline Carmadet & $\begin{array}{l}\text { from Karm (vineyard) + Hadet (proper } \\
\text { name) }\end{array}$ & $\mathrm{X}$ & $\mathrm{X}$ & $\mathrm{X}(\mathrm{R})$ \\
\hline Carrell & $\begin{array}{l}\text { from al-quraya? Diminutive of al-qarya (little } \\
\text { farmstead)? }\end{array}$ & $\mathrm{X}$ & & \\
\hline Cuñera & & $\mathrm{X}$ & & \\
\hline Daimés ${ }^{21}$ & from Damus (building) & $\mathrm{X}$ & $\mathrm{X}$ & \\
\hline Del Real ${ }^{22}$ & from Rabal (estate) & $\mathrm{X}$ & & $\mathrm{X}(\mathrm{O})$ \\
\hline $\operatorname{Franch}^{23}(\mathrm{~V})$ & "Franco", tax-free (Christian) & $\mathrm{X}$ & & $\mathrm{X}(\mathrm{L}, \mathrm{O})$ \\
\hline Jubalcoy & $\begin{array}{l}\text { from Yabl al-qull (white soils, of olive trees, } \\
\text { vineyards and cereal) }\end{array}$ & & & $\mathrm{X}(\mathrm{S})$ \\
\hline Madina Çadina & Madina Qadima ("old city"=La Alcudia) & & $\mathrm{X}$ & \\
\hline Marchena $^{24}$ & from al-marj (meadow, floodplain) & $\mathrm{X}$ & $\mathrm{X}$ & \\
\hline Matrof & from matruf (that rotates, related to mills) & $\mathrm{X}$ & & \\
\hline Nafís & $\begin{array}{l}\text { from nafis (adjective which means } \\
\text { productive, fertile, referring to irrigation } \\
\text { and lands/ proper name or surname }\end{array}$ & $\mathrm{X}$ & & \\
\hline Palombar & $\begin{array}{l}\text { Latin name that arrived to us from } \\
\text { Mozarabic. }\end{array}$ & $\mathrm{X}$ & & $\mathrm{X}(\mathrm{S}, \mathrm{O})$ \\
\hline Rabahalí & $\begin{array}{l}\text { patronymic of Arabian family, and ethnic } \\
\text { (for finishing with an -i) / rabah: Jewish } \\
\text { surname. The adjective "alí" (elevated) is } \\
\text { profusely used in Arabic onomastics }\end{array}$ & $\mathrm{X}$ & $\mathrm{X}$ & \\
\hline Rabat & from rabat (district) & & $\mathrm{X}$ & \\
\hline Sahoní & from sinhayi (Berber demonyc) & $\mathrm{X}$ & & $\mathrm{X}(\mathrm{O})$ \\
\hline Sinoga & from sinhaya (Berber lineage) & $\mathrm{X}$ & $\mathrm{X}$ & \\
\hline Ventarique & from Banu Tariq (patronymic+ proper name) & & & $\mathrm{X}(\mathrm{R})$ \\
\hline Xarquía $(\mathrm{La})$ & from sharq (east) & & $\mathrm{X}$ & \\
\hline
\end{tabular}

\subsection{Morphological aspects}

3.2.1 The unit of measurement in the Camp d'Elx: the tahúlla. Measures are really interesting and useful for establishing the origin of the buerta. The tabuilla is the surface unit used in the Camp $d^{\prime}$ Elx. It is considered to have an Islamic origin, not only because of its etymology but because of its confirmed existence at the time of the Christian conquest. This unit is used throughout Alicante, Murcia and Almería although with several different values (Romero, 2004).

In Elche and Crevillente the tabúlla is equivalent to $953 \mathrm{~m}^{2}$ while this same unit has a value of $1118 \mathrm{~m}^{2}$ in the rest of the places where it is used, particularly in Alicante, Murcia and Almería. The tabuilla corresponds to a square of 60 by 60 cubits (Romero, 2004), which means that it is based on the cubit. According to this, the rassasi cubit of $55 \mathrm{~cm}$ would have been used in the tabuilla of $1118 \mathrm{~m}^{2}$, while the tabuilla of Elche would have used the cubit of $51,75 \mathrm{~cm}$. This value is very close to the rassasi cubit of $52 \mathrm{~cm}$, which has been identified by Vallvé Bermejo as distinctive of the southeast of al-Andalus (Vallvé, 1976). This is also the current value of the cubit used in Morocco, and it corresponds to the ancient Egyptian royal cubit. We can therefore see that the pattern used to parcel up the lands of the Camp $d^{\prime} E l x$ is based on one of the variants of the Egyptian cubit, which became the official cubit in al-Andalus, at least until the end of the Caliphate. This allows

21 Common place name in North Africa and the East of the Iberian Peninsula.

22 Common place name at irrigation areas.

23 Place name present at Valencia.

24 The toponym Marchena has usually been interpreted as a Latin anthroponym (from Marcius), but we think it could come from the Arabic word marj, taking into account the physical characteristics of the territory where it is found. We also find this name in the buerta of Lorca (Murcia) (Jiménez, 1996) and in Andalucía. 
us to date the surveys carried out in the Camp $d^{\prime} E l x$ at a very early stage in the process, perhaps even before the development of the urban area.

We have confirmed that the size and design of the plots of the historical Palmeral are remarkably regular, not only with regard to the historic urban Palmeral but also regarding the rest of orchards, classified under the municipal Protection Plan as peri-urban, belonging to the riverbed (de cauce), neighbouring (limitrofe) and dispersed orchards. The regularity of the plots optimizes irrigation so they will always tend to be so, as far as possible. Yet, physical determinants or the need to respect the boundaries of a previous property may generate less regular shapes. It is highly significant that the historical plot has a defined area regardless of that of the property. In addition, there is a likely correspondence between this surface unit and those of the volume of water, namely, the fil and the talla. The first one, seems to have been used when the volume or flow of water is subject to time restrictions, while the talla (perhaps with the same etymology as the tabuilla) would have been used to refer to a water flow measurement without any time restriction, that is, until the land had been fully irrigated. In fact, in Orihuela, the volume of water is divided up in tabuillas, as written in the Repartimiento:

Otrosí, mandamos de parte del rey (...) que fagan a todos los herederos de Oriuela $(. .$.$) a limpiar e adovar las açarves et todas las acequias mayores e$ menores del término de Oriola, de guisa que vengan las aguas sin embargo neguno, así como venía en tiempos de moros. E que partan las aguas por atafullas, cada uno segunt lo que oviere, así como las avían drechamente en tiempo de moros (Glick, 2007: 194)

In Almería the equivalence between bilo, hour and tabuilla has been confirmed for irrigated lands, and in all cases an interdependency between the surface unit and the volume of water needed for its irrigation has been shown (Espinar and Abellán, 1998). All this means that the land would be parcelled up on the basis of its water needs, so the measuring of the land would be parallel or subsequent to the creation of hydraulic infrastructures.

An element of continuity in Andalusian agricultural practice after the Christian conquest is precisely the preservation of the tabuilla, specified in the privileges that the Castilian kingdom granted to the newly conquered town of Elche and later by Jaime II's royal decree under the Annexation Act to the Valencian kingdom. Keeping the tabuilla in use was one of the exceptions to Elche's general adherence to the Fuero de Valencia, granting the town "libre facultad de seguir sirviéndose de la tabuilla, como medida agraria propia, para la división de sus tierras y deslinde de sus términos"25 (Glick, 2007: 194). The preservation of the tabuilla until today shows the deep mark that Andalusian society has left on the organization of agrarian space, and it has also hindered the study of plots from a metric perspective as surface units belonging to the Christian feudal society are rarely used here.

3.2.2 The measures of structures. We also believe that the dimensions of the structures that organize this irrigation system could help us to deduce its origin. In this regard, as Enric Guinot has said in his work about such structures:

There are no records about the dimensions of the canals throughout their history. In fact, there is no need for them to be a specific measurement (...)

25 Original document in ACA, Rg.205, fol.188 v - 189 r) 
According to the measurements taken at many points along the Séquia Major of Elx between the intake (arud) and the city, we could say that nowadays they range between 2 and 3 meters wide, although it seems clear that original values would neither correspond to those of a decimal system nor to Valencian foral values from the $13^{\text {th }}$ to the $18^{\text {th }}$ century but to the values used by Islamic society (...) The same would apply to the canal of Marchena and the Font Antiga. (Guinot and Selma, 2003: 55)

Measurements of hydraulic infrastructures would have been more stable at the strategic points of the system where there was a special interest in controlling water flow and volume. At those points, construction would be more solid, as evidenced by the use of slabs and ashlar stones in the intake structures (azudes) and in all the dividers of the Séquia Major, both at the bottom and the sides of the division boxes. It is really meaningful to find such solid constructions which contrasts with the simple channels dug into the ground and strengthened with soil along the sides commonly found in many Valencian huertas. This reveals a particular interest in ensuring accurate proportions in the distribution of water, perhaps as a result of water being scarce.

The measurements for the dividers of the Séquia Major calculated by Francisco Verde in 1666 and completed in 1850 by Roca de Togores (De Hidalgo, 1851) have proven extremely useful for our chronological proposal. Their works provide several measurements, from which we have chosen two: those of the width of the sluice gates and of the division box bottom slab. Sluices are the places where the water that comes from the main canal flows through a divider. Their construction meets the need or the will to carry a specific quantity of water to one or more specific plots. Bottom slabs are also stable elements or, more appropriately, elements that seek to render the system stable and they would have had a dual role. On the one hand, these slabs would have preserved from erosion those parts of the Séquia Major more vulnerable to it, particularly where orographic factors cause turns or breaks. On the other hand, they would ensure an equal distribution of water. These measurements were originally in palms and digits, which are subunits of the Castilian $\operatorname{yard}^{26}$, so first we have converted them into the decimal system ${ }^{27}$ and then into each of the known values of the Islamic cubit, which are $47 \mathrm{~cm}$ for the mamuni cubit; and 52, 55 or $58,7 \mathrm{~cm}$ for the rassasi cubit (Vallvé, 1976). There are some measurements, especially those of the sluices that show subsequent amendments. To understand this we should take into account that the archival documentation shows significant illegal activity in the handling of water distribution, at least from the $16^{\text {th }}$ century onwards.

As a result of analysing the above mentioned measurements, we have drawn some conclusions. Firstly, we have observed that the vast majority of the measurements taken correspond to multiples or fractions of one of said cubits. After grouping together the dividers according to the kind of cubit that seemed to have been used in their construction, we could establish the following considerations: the general believe is that the rassasi cubit was the unit of measurement used during the Emirate and the Caliphate periods, while the mamuni cubit seems to have been used widely under the Almoravid and Almohad rules (Vallvé, 1976). We should then assume that the structures built using rassasi cubits would be older than those built using measures derived from the mamuni cubit. In connection to this, we think that the dividers that seem to have been entirely based on the

26 Vara, and its divisors palmo and dedo.

27 Colegio Oficial de Ingenieros Técnicos Agrícolas y Peritos Agrícolas de Alicante: Medidas superficiales antiguas, usadas en la provincia de Alicante y su equivalencia en unidades métricas. Source: www.dipalicante.es/coitapa 
rassasi cubits could be considered to belong to the original design. They would be the dividers of Albinella, Carrell, Nafis, Cuñera, Aladia-Franch, Palombar and Carmadet. There is also a proportionality between the sluice gate and the bottom slab of these dividers that leads us to believe that they were built at the same time - Albinella $1 / 2$ cubit for the sluice gate and 4 cubits for the bottom slab; Carrell $3 / 4$ cubit for the sluice gate and 4 cubits for the bottom slab; Nafis 1 cubit for the sluice gate and 4 cubits for the bottom slab; Cuñera 1 cubit for the sluice gate and 3 cubit for the bottom slab; and Palombar and Carmadet $3 / 4$ for the sluice gate and 2 cubits for the bottom slab.

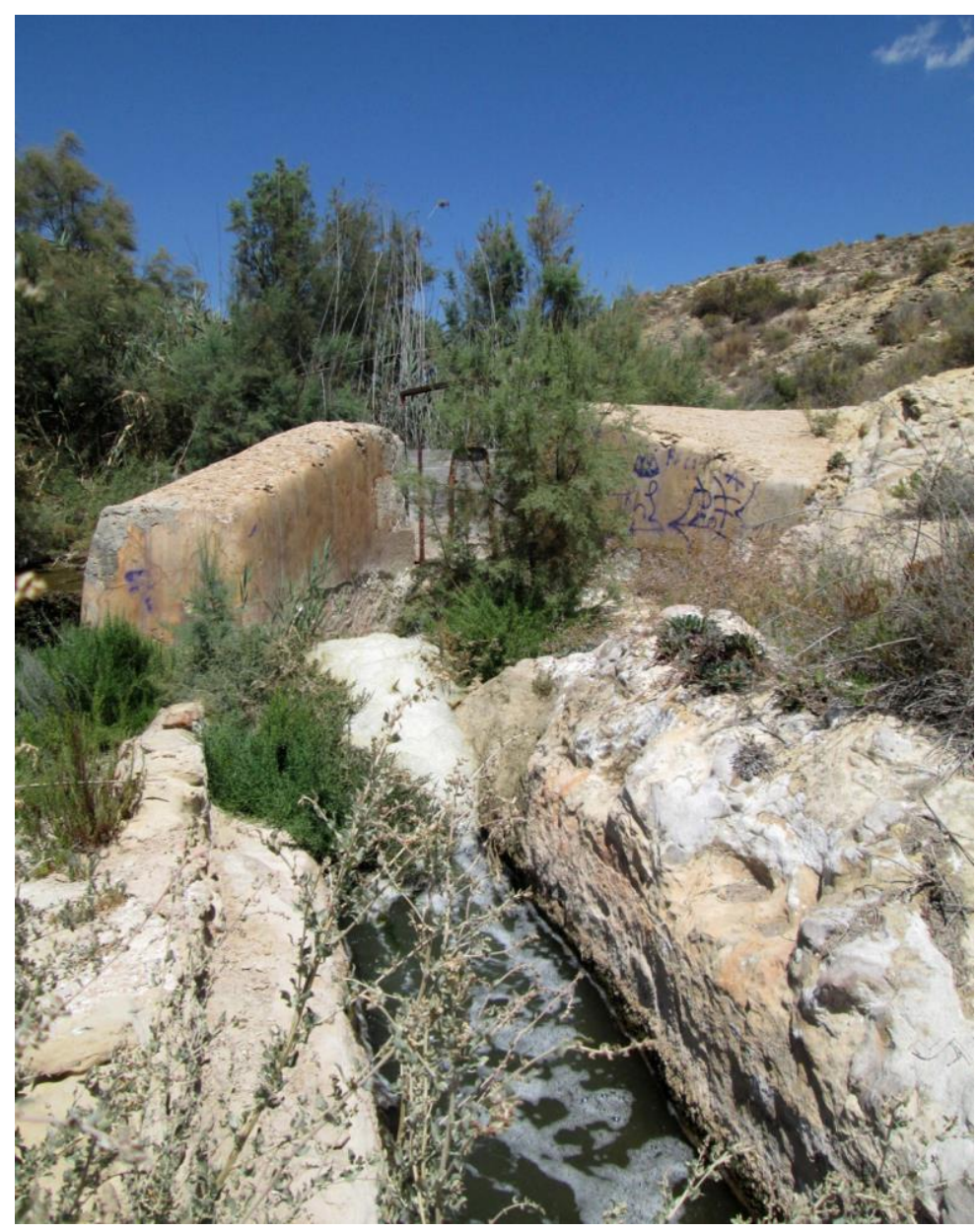

Fig.4: Intake structure (azud) and first section (dug out of the rock), Séquia Major. Photograph by D. Aviñó. 2013 


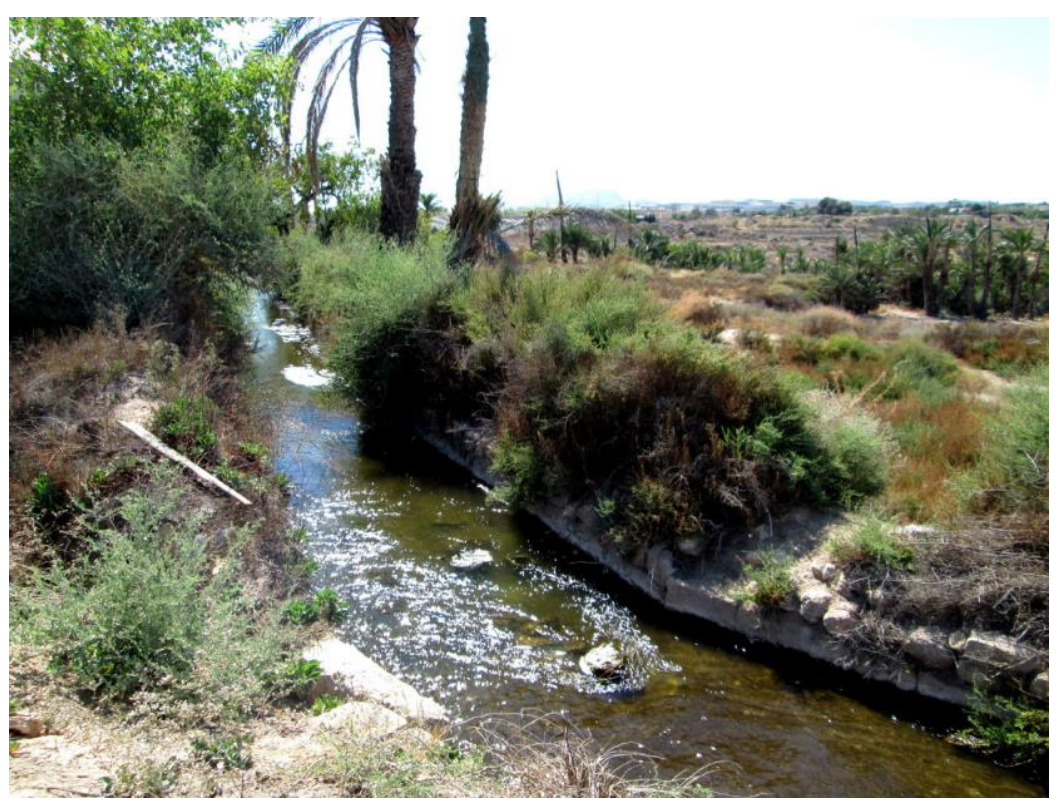

Fig.5: The Sequia Major arriving at its first divider, Albinella. Photograph by D. Aviñó. 2013

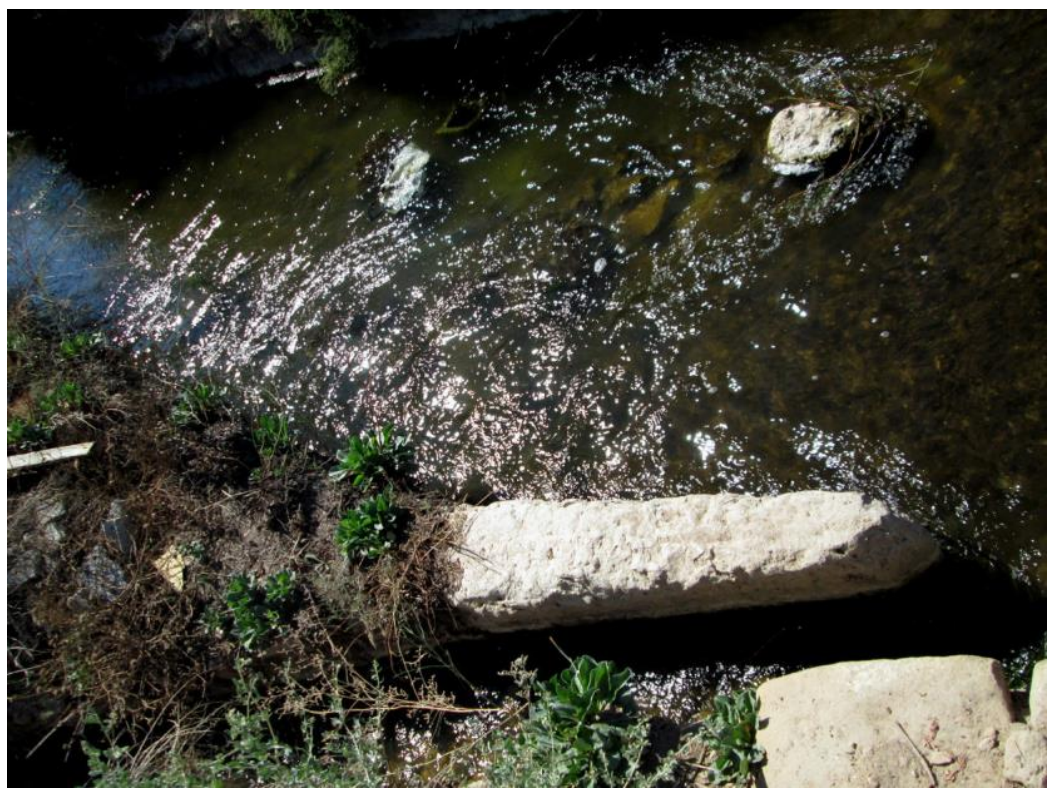

Fig.6: Divider of Albinella. Photograph by D. Aviñó. 2013 


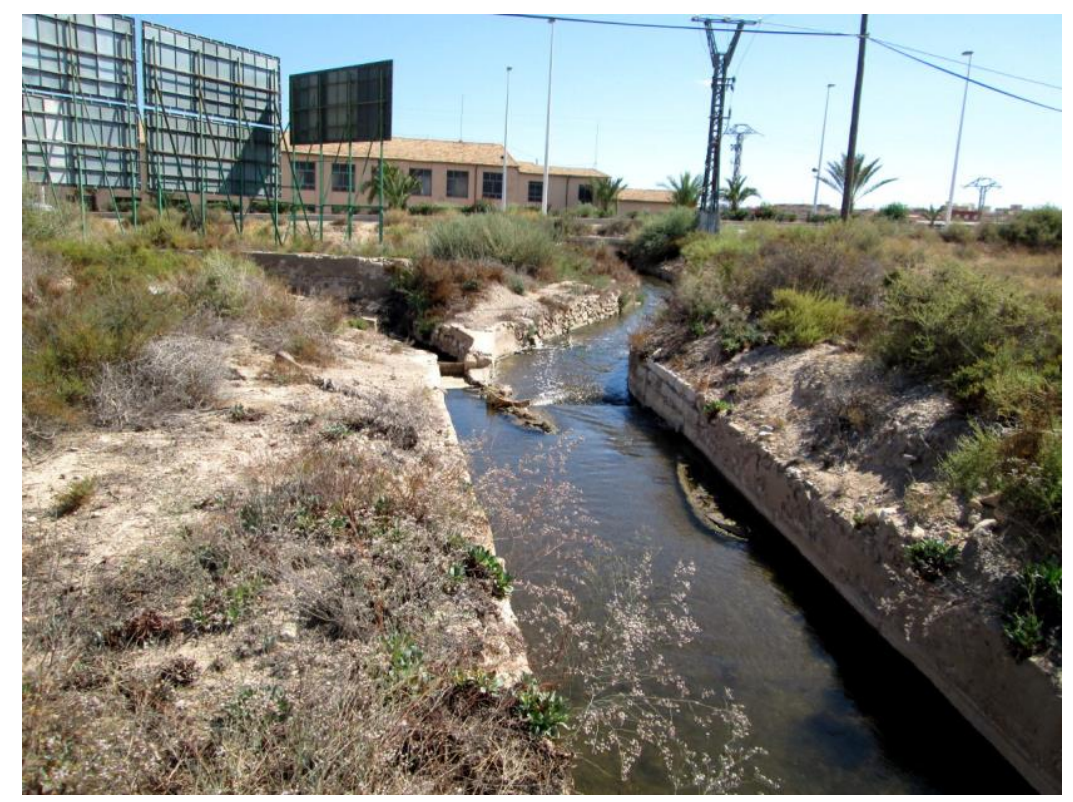

Fig.7: The Séquia Major arriving at the divider of Carrell. Photograph by D. Aviñó. 2013

The divider of Aladia-Franch occupies a key position in the whole system, and despite having been traditionally considered a later addition, the truth is that its measures correspond quite accurately to the rassasi cubit of $53 \mathrm{~cm}$. The water distributed by AladiaFranch belonged to the Infante Don Manuel, separately administered, as shown by the existence of another "book of waters" known as the "Llibre Xic" (De Hidalgo, 1851).

There are also some dividers with measurements based entirely on the mamuni cubit - also called surveyor cubit - that we consider to belong to an extension carried out during the Almoravid or Almohad periods as a result of the spread of the urban and peri-urban buertas. We are referring to the dividers of Anoy, probably Candalix-Huertos, and Alborrocat. Alinjassa also seems to belong to this later period, based on the measures of its bottom slab, equivalent to 4 mamuni cubits, although its sluice gate appears to have been modified at a later stage. This is one of the most often-mentioned dividers in lawsuits arising from the distribution of water, especially from the $16^{\text {th }}$ century.

However, the type of cubit used in both parts of the divider does not always coincide, and in these cases we must assume that each part was built at different times. With regard to the dividers that show this difference, we have some hypothesis depending on their specific circumstances. We think that those dividers whose sluice gate shows values related to a rassasi cubit could also belong to the original design even if their bottom slab show values related to the mamuni cubit because it could have been repaired at a later time. We are referring to the dividers of Abet, Atufà and Anaclà. On the other hand, the dividers of Matrof, Alcanà, Saoni and Alausa have bottom slabs with measures based on the rassasi cubit and sluice gates based on the mamuni cubit. We believe that these structures could also belong to the original design of the system, or at least would come within the planning of possible future extensions. From our point of view, the sluice gates of these dividers would have probably been rebuilt when the irrigation priorities changed and the alfoz of the city became the preferential irrigation zone. 


\section{Conclusions}

There is no doubt that hydraulic infrastructures are extremely useful when attempting to date an irrigation system. In our study, both the names and the measurements of these structures seem to reveal the Andalusian origin of the Huerta of Elche.

As we have seen when dealing with toponymy, the importance of Arabic place names closely related to irrigation structures - canals, ditches, dividers and farmsteads - is evident although the lack of Arabic names for the orchards that form the Historic Palmeral is also quite remarkable. For those names with an undoubtedly Arabic origin, we have been able to demonstrate the preponderance of common names - particularly descriptive ones - over proper names which appear in the most peripheral area of the system and coinciding with the names of farmsteads known from written sources. On the other hand, we have also come to conclude that the huerta nearest to the city would have undergone significant transformation after the Christian conquest, especially from the $17^{\text {th }}$ century onwards, which would explain the near absence of Arabic names for these orchards.

From our study of the measurements of the infrastructures we have found that the Séquia Major seems to respond to the notion of a unitary construction, from the place where the dividers start to the end of its course. The beginning and the end of the system would have been defined from the start, although new water outlets could have been added later as the need for water for other places appeared. The measures of the main canal along its course correspond to a carefully calculated design, which is shown, for instance, in the main canal's proportional decrease in width at each outlet, as the ratio between the outlet and the sluice gate of the secondary ditch increases. Hydraulic engineering principles inform this design process - as the water runs its course along the canal, the canal has to become narrower to keep the water speed constant. Likewise, the outlets of the lateral ditches should become wider the further down the course they are situated to ensure adequate flow intake. However, there is also evidence of this smooth cadence being interrupted at some of the dividers, which we think could have been built at a later stage, whether during the Andalusian period or after the Christian conquest. Another aspect that has drawn our attention is that, whichever cubit is used, the width of the bottom slabs has exact values of 4, 3 or 2 cubits. Along almost two thirds of its course, the canal is 4 cubits wide - whether rassasi or mamuni -, then it narrows to 3 cubits until its last three dividers where it is 2 cubits wide. At its last divider the canal has exactly half the width it had at its first divider - that of Albinella.

To sum up, the fact that almost every ditch in Elche's irrigation system has an Arabic name and that - as we have seen - these names are almost all descriptive shows clearly a close connection between their construction and Andalusian society. In addition, from our measure analysis we have also found strong evidence to support our thesis, not only because of the use of the tabulla as the main surface unit in the huerta but also because of the presence of the cubit throughout the irrigation system. 


\section{References}

Asín Palacios, M. (1944): Contribución a la toponimia árabe de España, Madrid- Granada.

Barceló Torres, C. (1982a): Toponímia aràbica del País Valencià. Alqueries i castells, Xàtiva.

Barceló Torres, C. (1982b): De toponímia tribal i clànica berber a les illes orientals d'AlAndalus, Butlletí de la Societat d'Onomàstica 10, pp. 42-46.

Barceló, M. (1989): El diseño de espacios irrigados en al-Andalus: un enunciado de principios generales, I Coloquio de Historia y Medio Físico, Almería, Instituto de Estudios Almerienses, Departamento de Historia.

Bazzana, A. (1980): Premiers éléments d'une carte archéologique du Shark-al-Andalus, Archéologie médiévale 10, pp. 309-332.

Bazzana, A. (1986): Irrigation et maitrise de l'eau dans l'Espagne médiévale. Quelques remarques méthodologiques, Revue Géographique de l'Est, vol. 26, 3-4, pp. 199-204.

Bertrand, M and Cressier, P. (1985): Irrigation et aménagement du terroir dans la vallèe de l'Andarax (Almería ): les réseaux anciens de Ragol, Melanges de la Casa de Velázquez 21, pp. 115-136.

Borrego, M. and Saranova, R. (1990): La ciudad islámica de Elche. Fortificación y espacios urbanos, Boletin de Arqueología Medieval 4, pp. 173-194.

Caridad Arias, J. (2004): Los fenómenos de homonimia y homofonía en la toponomástica y su repercusión en las etimologías cultistas y populares de la Europa Occidental, Doctoral Thesis, Universidad de la Laguna. Digital edition: ftp://tesis.bbtk.ull.es/ccssyhum/cs157.pdf

Colegio Oficial de Ingenieros Técnicos Agrícolas y Peritos Agrícolas de Alicante: Medidas superficiales antiguas, usadas en la provincia de Alicante y su equivalencia en unidades métricas. Source: www.dip-alicante.es/coitapa

Cressier, P. (1989): Archeologie des structures hydrauliques en Al-Andalus, El agua en zonas áridas. Arqueología e historia. Hidráulica tradicional de la provincia de Almería / coord. Lorenzo Cara Barrionuevo, pp. 2051-2092.

De Epalza, M. y Rubiera Mata, M. J. (1986): Estat actual dels estudis de toponímia valenciana d'origen àrab, X Col.loqui General de la Societat d'Onomàstica, I d'Onomàstica Valenciana, Valencia, pp .420-426.

De Hidalgo Tablada, D. J. (1851): Manual de Riegos y aplicación de las aguas aluvión al cultivo de tierras. Establecimiento de los prados naturales y artificiales, El Agrónomo, Madrid.

Espinar Moreno, M. and Abellán Pérez, J. (1998): Captación, distribución y usos del agua en las ciudades musulmanas: el caso de Almería, Guadix y Granada, Miscelánea Medieval Murciana XXI-XXII, pp. 83-110. 
Esquilache Martí, F. (2011): Prospectar huertas y vegas fluviales. El estudio del paisaje histórico andalusi de la buerta de Valencia: Arqueología y análisis morfológico. Source: www.arqueologiamedieval.com

Faure Sabater, R. (1977): Toponimia de la Vall de Gallinera, Alicante.

Glick, T. F. (1988): Regadío y sociedad en la Valencia medieval, Valencia, Del Cenia al Segura.

Glick, T. F. (1992): Tecnología, ciencia y cultura en la España medieval, Alianza Universidad.

Glick, T. F. (2007): Paisajes de conquista. Cambio cultural y geográfico en la España medieval, Valencia, Universidad de Valencia.

González Villaescusa, R. (1996): Paisaje agrario, regadío y parcelarios en la huerta de Valencia. Nuevos planteamientos desde el análisis morfológico, II Coloquio de Historia y Medio físico. Agricultura y regadío en al-Andalus, pp. 343-360.

González Villaescusa, R. (2002): Centuriaciones, alquerías y pueblas, elementos para la comprensión del paisaje valenciano. (Una revisión seis años después), Las formas de los paisajes mediterráneos, Jaén, 2002, pp. 425-472

Guichard, P. (1985): El Islam alicantino, Historia de la provincia de Alicante, tomo III, Murcia.

Guichard, P. (1991): La toponymie tribale berbère valencienne: Response a quelques objections philologiques, Festgabe für Hans-Rudolph Singer, Frankfurt, pp.125-141.

Guichard, P. (1994): La formación de al-Andalus, La formación del feudalismo en el mundo mediterráneo, Granada, Universidad de Granada.

Guichard, P. (1995): Al-Andalus. Estructura antropológica de una sociedad islámica de occidente, Estudio preliminar por Antonio Malpica, Granada, Servicio de Publicaciones de la Universidad de Granada.

Guinot, E. and Selma, S. (2003): Las acequias de Elche y Crevillente, Camins d'Aigua 4, El patrimonio hidráulico valenciano. Generalitat Valenciana, Conselleria d'Agricultura, Peixca i Alimentació.

Guinot, E. (2007): Una historia de la huerta de Valencia, El patrimonio bidráulico del Bajo Turia: L'Horta de València, I. Contexto Geográfico e Histórico de los regadios de la Huerta de Valencia. (Cap. 3), Dir. Jorge Hermosilla Pla. Confederación Hidrográfica del Júcar.

Hernández Carrasco, C. (1976): El árabe en la toponimia murciana, Digitum, Universidad de Murcia, pp.153-255.

Montesinos García, J. A. (Coord.) (2004): Informe sobre la Acequia Mayor de Elche y sus construcciones asociadas. Comissió de Llegat Històric i Artístic. Consell Valencià de Cultura.

Ivars Cervera, J. (2003): La toponimia de la Marina Alta a l'Onomasticon Cataloniae, de Joan Coromines", Butlletí Interior de la Societat d'Onomàstica, 94-95, pp. 439-468.

Jaén i Urban, G. (2002): De com es regaven els horts de palmeres d'Elx, Revista Mètode 35, Universitat de València. Source: http://metode.cat/Revistes/Article/De-com-es-regavenels-horts-de-palmeres-d-Elx

Jacinto García, E. J. (2006): La toponimia de Jaén en las fuentes árabes medievales: aproximación lingüística", Actas del XXXV Simposio Internacional de la Sociedad Española de Lingüistica, pp. 1004-1026. 
Jiménez Alcázar, J. F. (1996): Agua y poder en Lorca durante la Baja Edad Media. Universidad de Murcia.

Kirchner, H. and Navarro, C. (1994): Objetivos, métodos y práctica de la arqueología hidráulica, Arqueología y territorio medieval 1, pp. 159-182.

López Gómez, A. (1987): La agricultura de Valencia a principios del siglo XVII según Escolano, Estructuras y regimenes de tenencia de la tierra en España, pp. 495-514.

Manzano Martínez, J. A. (1995): Aproximación a la problemática histórica de un espacio hidráulico: la huerta de Murcia, Memorias de Arqueología, Murcia.

Martínez, L. P. (1999): El Palmeral de Elche: un paisaje español de regadío heredado de al-Andalus, Generalitat Valenciana, Conselleria de Cultura, Educació i Ciència.

Oliver Pérez, D. (2001): La toponimia como reflejo de movimientos migratorios entre el Magreb, España y América Latina, Al-Andalus Magreb, Estudios árabes e islámicos 8-9, pp. 281 297.

Pocklington, R. (2010): Toponimia ibérica, latina y árabe de la Provincia de Albacete, AlBasit: Revista de estudios albacetenses 55, pp. 111-167.

Ranz Yubero, J. A. and López de los Mozos, J. R. (1997): Topónimos defensivos que aparecen en las relaciones topográficas de Felipe II, Wad-al-Hayara: Revista de estudios de Guadalajara 24, pp. 317-334.

Romero García, R. E. (2004): Medidas antiguas españolas. Breve compendio de las medidas antiguas utilizadas en las diferentes regiones y provincias españolas, Técnica Industrial 254.

Roselló Bordoy, G. (2007): Mallorca musulmana, Universidad de las Islas Baleares.

Rubiera Mata, M. J. (1985): Villena en las calzadas romanas y árabes, Alicante.

Serrano Barceló, V. (1996): Huertos que ban babido y aun quedan en Elche, Elche.

Serrano i Jaén, J. (1992): La comunitat morisca del raval d'Elx a la vigília de la seua expulsió (1600-1609), Estudis d' Història agrària 9, pp. 7-39.

Vallvé Bermejo, J. (1976): Notas de metrología hispano-árabe. El codo en la España musulmana, Al-Andalus, 41, pp. 339-354. 